\title{
Faktor-faktor yang Berhubungan dengan Tingkat Pengetahuan Orang Tua terhadap Pendidikan Seksual pada Anak Usia Dini di Sekolah Dasar Kartika VIII-5 Jakarta Selatan Tahun 2014
}

\author{
LEGINA ANGGRAENI \\ Fakultas Kesehatan Masyarakat Universitas Indonesia \\ Email: legina_anggraeni@yahoo.com
}

Article Received: 10-01-2018

Published Article: 03-04-2018

DOI: https://doi.org/10.29313/ga.v1i2.3383

\begin{abstract}
There are a few people, especially parents, who care about the sex education of children. They assumed that sex education is prohibited to be taught to children. Even though, early childhood sex education introduces the body parts and their functions to the children and able to prevent them from the crimes of sexual. This study aims to seek the factors associated with the level of parents knowledge of early sex education to the children at Kartika VIII-5 Elementary School, South Jakarta, in 2014. The result indicates that there is a significant relationship between education, social and cultural value, and exposure of information with the level of parents knowledge of sex education. Whereas, the occupation, age, and experience have no significant relationship with the level of parents knowledge of early sex education to the children.
\end{abstract}

Keywords: knowledge, sexual education, children, and parents.

\begin{abstract}
Abstrak
Sedikit sekali masyarakat terutama orang tua yang peduli akan pendidikan seksual pada anak dan beranggapan bahwa pendidikan seksual merupakan hal yang tabu untuk diberikan kepada anak. Padahal pendidikan seksual secara dini bertujuan untuk memperkenalkan kepada anak anggota tubuh yang dimiliki beserta dengan fungsifungsinya. Selain itu, pendidikan seksual juga bertujuan untuk menghindarkan anak dari tindak kejahatan penyimpangan seksual. Penelitian ini bertujuan untuk melihat faktor-faktor yang berhubungan dengan tingkat pengetahuan orang tua terhadap pendidikan seksual secara dini pada anak di Sekolah Dasar Kartika VIII-5 Jakarta Selatan tahun 2014. Hasil penelitian ini menunjukan bahwa ada hubungan yang bermakna antara pendidikan, nilai sosial budaya dan keterpaparan informasi dengan tingkat penegtahuan orang tua terhadap pendidikan seksual pada anak. Sedangkan pekerjaan, umur, dan pengalaman pendidikan seksual yang pernah diterima oleh orang tua pada masa anak-anak tidak mempunyai hubungan yang bermakna.
\end{abstract}

Kata kunci : pengetahuan, pendidikan seksual, anak, dan orang tua.

\section{Pendahuluan}

Pendidikan seksual pada anak masih dianggap tabu oleh sebagian besar masyarakat. Mereka beranggapan pendidikan seksual hanya mengajarkan anak tentang seksualitas tanpa menghadirkan unsur pendidikan didalamnya. Menurut Skripsiadi (2005) ada beberapa hal yang membuat masyarakat merasa tabu salah satu diantaranya adalah faktor budaya yang melarang pembicaraan mengenai seks di depan umum, karena dianggap sebagai sesuatu yang porno dan sifatnya sangat pribadi sehingga tidak boleh diungkapkan ke khalayak ramai.

Akibatnya orang tua menjadi takut, bingung, malu sehingga menghambat orang 
tua itu sendiri untuk memberikan informasi yang benar terkait pendidikan seksual. Padahal informasi mengenai seksualitas sangat dibutuhkan dalam tahapan perkembangan anak itu sendiri (Sugiasih, 2005). Banyak orang tua yang tidak memberikan pendidikan seks pada anak, dengan alasan anak akan tau dengan sendirinya. Mereka beranggapan membicarakan seks kepada anak adalah suatu hal yang tabu (Oktaufik, 2010). Seringkali orang tua beranggapan bahwa anak kecil tidak perlu dan belum pantas mendapat pendidikan seks. Orang tua berkeyakinan bahwa ketika anak memasuki akil baligh (pubertas), pendidikan seks akan diberikan, bahkan orang tua beranggapan jika anak sudah besar nanti akan mengetahuinya sendiri (Sugiasih, 2005).

Pendidikan seksual yang tepat akan membantu anak lebih memahami tentang konsep dirinya sendiri, sehingga anak tersebut akan memahami tentang tubuhnya sendiri. Hal ini sangatlah penting untuk menghindari tindakan pelecehan seksual pada anak. Namun sayangnya, orang tua seakan "malumalu" dalam memberikan pendidikan seksual pada anak-anaknya. Meskipun orang tua merasa malu untuk membicarakan masalah tersebut, tetapi sebenarnya mereka setuju bahwa pendidikan seksual itu dibutuhkan (Roqib, 2008). Menurut Nugraha (2009), di Indonesia sebesar $80 \%$ ibu tidak sanggup memberikan pendidikan seks dirumah alasannya mereka tidak tahu apa yang harus dan layak disampaikan. Hanya sebesar $25 \%$ ibu yang memberikan pendidikan seks dini dengan dibacakan, melihat gambar-gambar sambil diterangkan dari buku-buku dongeng, nyanyian anak, dll. Pada umumnya orang tua menganggap bahwa pendidikan seks hanya berisi tentang pemberian informasi alat kelamin dan berbagai macam posisi dalam berhubungan seksual, dan hal inilah yang sebenarnya dikhawatirkan orang tua. Kenyataannya, pendidikan seks pada anak usia dini menjelaskan tentang organ-organ yang dimiliki manusia dan apa fungsinya (Puspitosari, 2013).

Pendidikan seks sebenarnya mempunyai pengertian yang jauh lebih luas, yaitu upaya memberikan pengetahuan tentang perubahan biologis, psikologis, dan psikososial sebagai akibat pertumbuhan dan perkembangan manusia (Lasari, 2012). Dengan demikian kita dapat memberitahukan kepada anak bahwa seks adalah hal yang alamiah dan wajar, selain itu kita juga dapat memberitahu dampak dari tindakan berisiko seperti sex bebas pada kehidupannya. Pemberian pendidikan seks harus sesuai dengan usia anak tersebut. Seperti pada usia balita, tujuannya adalah untuk memperkenalkan organ-organ tubuh yang dimiliki. Untuk usia sekolah mulai 6-10 tahun bertujuan memahami perbedaan jenis kelamin (laki -laki dan perernpuan). Untuk usia remaja pendidikan seks bertujuan untuk menginformasikan masa pubertas dan penjelasan mengenai perilaku seks yang merugikan seperti seks bebas (Qudsy, 2012). Pendidikan seksual mutlak diperlukan sepanjang hidup manusia. Sejak terlahir, setiap manusia mempunyai perangkat yang berkaitan dengan reproduksi sehingga mau tidak mau, ilmu tentang memahami seksualitas secara benar sangat diperlukan. Dengan demikian, anak tidak berbuat sesuka hati dan tanpa landasan tanggung jawab yang kuat dalam memperlakukan tubuhnya.

\section{Metodelogi Penelitian}

Metode yang digunakan dalam penelitian ini adalah deskriptif analitik dengan pendekatan studi Cross Sectional. Penelitian ini dilakukan di Sekolah Dasar Kartika VIII-5, Jakarta Selatan pada tahun 2014. Sampel yang digunakan pada penelitian ini berjumlah 60 orang. Dalam penelitian ini, data yang dikumpulkan merupakan data primer yang diperoleh dari angket yang disebarkan di Sekolah Dasar Kartika VIII-5 Jakarta Selatan, Jakarta Selatan. Data yang telah diperoleh kemudian diolah dan dianalisis secara univariat dan bivariat dengan menggunakan uji chi square. Kemudian, data yang tersebut disajikan dalam bentuk tabel serta dilengkapi dengan penjelasan serta analisis hubungan antara variabel dependen dengan variabel independen.

\section{Hasil dan Pembahasan}

Berdasarkan hasil penelitian terhadap 60 orang tua siswa yang bersekolah di Sekolah Dasar Kartika VIII-5 didapati hasil sebagai berikut. 
Tabel 1

\begin{tabular}{|c|c|c|c|c|}
\hline No & Variabel & Kategori & Jumlah (orang) & Persentase (\%) \\
\hline \multirow[t]{2}{*}{1} & \multirow[t]{2}{*}{ Pengetahuan } & Baik & 56 & 93,3 \\
\hline & & Kurang & 4 & 6,7 \\
\hline \multirow[t]{2}{*}{2} & \multirow[t]{2}{*}{ Pendidikan } & Tinggi & 55 & 91,7 \\
\hline & & Rendah & 5 & 8,3 \\
\hline \multirow[t]{2}{*}{3} & \multirow[t]{2}{*}{ Pekerjaan } & Bekerja & 34 & 56,7 \\
\hline & & Tidak bekerja & 26 & 43,3 \\
\hline \multirow[t]{2}{*}{4} & \multirow[t]{2}{*}{ Umur } & Dewasa awal & 25 & 41,7 \\
\hline & & Dewasa akhir & 35 & 58,3 \\
\hline \multirow[t]{2}{*}{5} & \multirow[t]{2}{*}{ Pengalaman } & Ada & 23 & 38,3 \\
\hline & & Tidak ada & 37 & 61,7 \\
\hline \multirow[t]{2}{*}{6} & \multirow[t]{2}{*}{ Nilai sosial Budaya } & Tabu & 17 & 28,3 \\
\hline & & Tidak tabu & 43 & 71,7 \\
\hline \multirow[t]{2}{*}{7} & \multirow{2}{*}{$\begin{array}{l}\text { Keterpaparan } \\
\text { Informasi }\end{array}$} & Terpapar & 48 & 80 \\
\hline & & Tidak terpapar & 12 & 20 \\
\hline
\end{tabular}

Berdasarkan hasil uji Chi Square, diperoleh $p$-value sebesar 0,001. Artinya terdapat hubungan yang signifikan antara pendidikan dengan tingkat pengetahuan orang tua terhadap pendidikan seksual secara dini pada anak. Hal ini sesuai dengan teori yang disampaikan oleh Mubarok (2012) yang menyatakan bahwa tidak dapat dipungkiri bahwa semakin tinggi pendidikan seseorang, semakin mudah pula mereka menerima informasi, dan pada akhirnya pengetahuan yang dimilikinya akan semakin banyak. Sebaliknya, jika seseorang memiliki tingkat pendidikan yang rendah, maka akan menghambat perkembangan sikap orang tersebut terhadap peneriman informasi dan nilai-nilai yang baru diperkenalkan. Namun hasil penelitian diatas berbeda dengan penelitian sebelumnya yang dilakukan oleh Anisah (2009) di Cianjur, Jawa Barat yang menyatakan bahwa tidak ada hubungan yang signifikan antara pendidikan dengan tingkat pengetahuan orang tua terhadap pendidikan yaitu dengan $p$-value $=0,717$. Perbedaan dari hasil penelitian yang dilakukan dengan hasil penelitian Anisah (2009) dikarenakan peneliti lain melakukan penelitian di daerah pedesaan yang sebagian besar masyarakatnya berpendidikan rendah sehingga pengetahuan mereka akan pendidikan seksual masih sangat minim.

Berdasarkan hasil uji Chi Square, diperoleh $p$-value sebesar 0,186 artinya tidak terdapat hubungan antara pekerjaan dengan tingkat pengetahuan orang tua terhadap pendidikan seksual secara dini pada anak.
Hasil penelitian ini didukung oleh penelitian sebelumnya yang dilakukan oleh Anisah (2009) yang menyatakan bahwa tidak ada hubungan antara pekerjaan dengan tingkat pengetahuan terhadap pendidikan seks $P=0,35$. Namun hal ini tidak sejalan dengan teori yang menyatakan bahwa pengetahuan seseorang yang bekerja akan lebih baik dari pada pengetahuan orang yang tidak bekerja. Hal ini dikarenakan teori diatas membahas tentang pengetahuan/wawasan secara umum bukan pengetahuan khusus yang membahas mengenai pendidikan seksual secara dini pada anak. Seseorang yang berpendidikan tinggi belum tentu mengetahui tentang materi pendidikan seksual secara dini pada anak.

Berdasarkan hasil uji Chi Square, diperoleh $p$-value sebesar 0,726 artinya tidak terdapat hubungan antara umur dengan tingkat pengetahuan orang tua terhadap pendidikan seksual secara dini pada anak. Hasil penelitian ini sejalan dengan penelitian yang telah dilakukan oleh Meyda (2010) yang menyatakan bahwa tidak ada hubungan yang bermakna antara usia orang tua dengan tingkat pengetahuan orang tua terhadap pendidikan seksual dengan $p$-value 0,209 ( $P$ $>0,05)$. Namun hal ini tidak sesuai dengan apa yang dipaparkan oleh Solikhati (2012) yang menyatakan bahwa usia mempengaruhi terhadap daya tangkap dan pola pikir seseorang. Semakin bertambah usia akan semakin berkembang pula daya tangkap dan pola pikirnya, sehingga pengetahuan yang diperolehnya semakin membaik. Perbedaan ini dikarenakan dalam penelitian 
ini peneliti mengkategorikan responden dalam satu klasifikasi umur (dewasa) sehingga responden dalam penelitian ini memiliki umur yang homogen oleh karena itu dari hasil penelitian didapatkan tidak ada hubungan yang bermakna antara umur dengan tingkat pengetahuan.

Berdasarkan hasil uji Chi Square, diperoleh $p$-value sebesar 0,57 artinya tidak terdapat hubungan antara pengalaman dengan tingkat pengetahuan orang tua terhadap pendidikan seksual secara dini pada anak. Hasil penelitian ini didukung dengan penelitian sebelumnya yang dilakukan oleh Putri (2012) yang menyatakan bahwa tidak ada hubungan yang signifikan antara pengalaman dengan tingkat pengetahuan orang tua dengan $p$-value $=0,201$. Sedangkan penelitian yang lain juga menyatakan hal yang sama dengan nilai $P=$ $0,153$ ( $P>0,05)$ (Anisah, 2009). Hal ini tidak sesuai dengan teori yang disampaikan oleh Ali dan Asrori (2008) yang menyatakan bahwa, pengalaman akan pendidikan seksual dalam kehidupan keluarga sebelumnya (masa kanakkanak/ remaja) merupakan intervensi yang dilakukan orang tua dalam pembentukan pengetahuan individu. Dalam penelitian ini sebagian besar responden berpendidikan tinggi dan tinggal di kota besar sehingga mereka dapat lebih mudah untuk mengakses informasi mengenai pendidikan seksual pada anak baik dari media cetak maupun media elektronik. Sehingga pengalaman pemberian pendidikan seksual di masa anak-anak tidak berkontribusi besar dalam meningkatkan pengetahuan responden.

Berdasarkan hasil uji Chi Square, diperoleh $p$-value sebesar 0,001 artinya terdapat hubungan antara nilai sosial dengan tingkat pengetahuan orang tua terhadap pendidikan seksual secara dini pada anak. Hasil penelitian ini sejalan dengan penelitian yang dilakukan oleh Meyda (2010) di Malang yang menyatakan bhwa ada hubungan yang bermakna antara nilai sosial budaya dengan tingkat pengetahuan dengan $\mathrm{p}$-value

$=0,03$. Hal ini juga sesuai dengan teori yang dipaparkan oleh Rahman (2013) yang menyatakan bahwa, pandangan atau nilai yang dianut di masyarakat mengenai pendidikan seks masih sangat sempit. Sebagian besar orang tua masih menganggap membicarakan tentang pendidikan seks adalah hal tabu dan tidak tepat bila diberikan kepada anak. Orang tua hanya berfokus kepada pendidikan formal yang dijalani oleh anaknya. Latar belakang budaya orang tua mempengaruhi nilai-nilai apa yang akan diwariskan pada anak dalam keluarga tersebut melalui pola asuh yang diterapkan. Budaya Timur mengidentikan hal yang berbau seksual adalah tabu dapat menghambat orang tua untuk melaksanakan pendidikan seksual pada anak dan remaja (Anisah, 2009). Penelitian diatas dilakukan di daerah Jakarta (kota besar) dimana reponden (orang tua) berasal dari berbagai suku (heterogen) di Indonesia sehingga mempunyai nilai/pandangan yang berbeda mengenai pendidikan seksual pada anak.

Berdasarkan hasil uji Chi Square, diperoleh $p$-valer sebesar 0,004 artinya terdapat hubungan antara keterpaparan informasi dengan tingkat pengetahuan orang tua terhadap pendidikan seksual secara dini pada anak. Hasil penelitian ini didukung oleh penelitian yang dilakukan oleh Putri (2012) yang menyatakan ada hubungan antara keterpaparan informasi dengan tingkat pengetahuan orang tua dengan $p$-value sebesar 0,026 $(P<0,05)$. Responden dalam penelitian ini berada di kota besar yang notabennya mudah untuk mengakses informasi mengenai pendidikan seks untuk anak. Sehingga responden dalam hal ini adalah orang tua mampu untuk memberikan pemahaman kepada anaknya tentang pendidikan seks secara dini.

\section{Kesimpulan}

Berdasarkan penelitian yang telah dilakukan kepada 60 responden mengenai faktor-faktor yang berhubungan dengan tingkat pengetahuan orang tua terhadap pendidikan seks secara dini pada anak di Sekolah Dasar Kartika VIII-5, Jakarta Selatan maka dapat disimpulkan bahwa berdasarkan hasil penelitian yang dilakukan di SD Kartika VIII-5, Jakarta Selatan diperoleh orang tua dengan tingkat pengetahuan baik sebanyak 56 orang $(93,3 \%)$ dan tingkat pengetahuan kurang sebanyak 4 orang $(6,7 \%)$. Variabelvariabel yang berhubungan adalah pendidikan, nilai sosial budaya dan keterpaparan informasi. Sementara variabelvariabel yang tidak berhubungan, diantaranya pekerjaan, umur dan pengalaman.

\section{Daftar Pustaka}

Ali dan Asrori. (2008). Psikologi Remaja: Perkembangan Peserta Didik. PT Bumi Aksara: Jakarta

Anisah, Ani. (2009). Faktor-faktor Yang 
Berhubungan Dengan Pengetahuan dan Sikap Orang Tua Terhadap Pendidikan Seksual di Kampung Parabon RW 03 Desa Ciloto Kabupaten Ciganjur. Skripsi: Depok.

Chomaria, Nurul. (2012). Pendidikan Seks Untuk Anak. Penerbit Aqwam: Solo.

Lasari, Rizma. F. (2012). Pendidikan Seks Untuk Anak Sekolah Dasar. Artikel: Jakarta.

Meyda, Dwinda. (2010). Hubungan Antara Tingkat Pengetahuan Ibu Tentang Perkembangan Psikoseksual Anak Dengan Pendidikan Seks Usia Dini Terhadap Anak Usia Pra sekolah (4-6 tahun) di TK Cempaka Kelurahan Ketawanggede Kota Malang. Skripsi: Depok.

Mubarok, Wahit. I. (2012). Promosi Kesehatan Untuk Kebidanan. Salemba Medika: Jakarta.

Nugraha, Boyke. (2009). Bicara Seks Bersama Anak. Pustaka Anggrek: Yogyakarta.

Oktaufik, Raman. S. (2010). Pentingnya Pendidikan Seks Pada Anak. Artikel: Jakarta.
Puspitosari, Widyawati. (2015). Peran Orang Tua Dalam Pendidikan Seks Pada Remaja. Universitas Muhammadiyah Jakarta.

Putri, Imanda. K. (2012). Faktor-faktor yang Berhubungan Dengan Perilaku Pemberian Pendidikan Seks Untuk Anak Oleh Orang Tua Siswa Madrasah Ibtidaiyah Hayatul Islamiyah. Skripsi: Depok.

Qudsy, Hasan. (2012). Ketika Anak Bertanya Tentang Seks. Tinta Medina: Solo.

Roqib, Muhammad. Pendidikan Seks untuk anak usia dini. Insania Vol. 13 No 2 MeiAgustus 2008

Skripsiadi, Erwin. (2005). Pendidikan dasar seks untuk anak sebagai panduan diskusi dalam keluarga. Curiosita: Yogyakarta.

Solikhati, Anisa. (2012). Jenis-jenis Pengetahuan. Artikel: Surabaya.

Sugiasih, Inhastuti. (2005). Need Assessment mengenai pemberian pendidikan seksual yang dilakukan ibu untuk anak usia 3-5 tahun. Proyeksi Vol 6 No.1. 
Golden Age: Jurnal Pendidikan Anak Usia Dini, Volume 1 Nomor 2 (Desember 2017)

LEGINA ANGGRAENI / Faktor-faktor yang Berhubungan dengan Tingkat Pengetahuan Orang Tua terhadap Pendidikan Seksual pada Anak Usia Dini di Sekolah Dasar Kartika VIII-5 Jakarta Selatan Tahun 2014 